\title{
The Adriatic-Baltic Transversal: Danilo Kiš Through the Prism of Baltic Writing on Essentialism and Diversity
}

\author{
JOHN K. COX
}

\begin{abstract}
The purpose of this paper will be to compare the ideas of one highly regarded southeast European writer, Danilo Kiš (1935-1989) of Yugoslavia, with those of some leading writers and thinkers from the Latvia, Estonia, and Lithuania. My analysis will center on the vague concepts of "identity" and "national culture". I will explore, by reference to the many essays and interviews of DaniloKiš, concrete topics such as essentialism and linguistic and ethnic diversity and look for parallels or contrast in the works of some Baltic writers. These thoughts will, I hope, spark a discussion based on sources broader than those that I command about what terms such as identity and national culture actually mean and how they effect the production, or reputation, of writers. It should also be possible to look at some issues relating to cultural translation in Kiš, because he grew up in the contested border area between Hungary and Serbia, was the product of an ethnically and religiously mixed marriage, and translated and taught internationally for much of his life.
\end{abstract}

Keywords: CentralEurope, the Baltics, Balticliterature, the Balkans, postcolonialism, regional identity, nationalism

\section{Introduction}

As a historian specializing in the intellectual history of the modern Balkans, and with an avocation as a literary translator, it is my goal today to examine, from the perspective of the work of the Yugoslav novelist and essayist Danilo Kiš (1935-1989), some of the common concepts that link many of the individual papers here. To set the stage, I would first like to read two quotes from Kiš's essays. The first comprises part of his famous diatribe against nationalism (a term that for him includes the "holy grail" of national identity, too), and it was written in 1978, before Tito's death and Yugoslavia's slide towards dissolution:

Nationalism is first and foremost paranoia, individual and collective paranoia. As collective paranoia it is the product of envy and fear and primarily the result of a loss of individual consciousness... Thus, nationalism is the path of least resistance, the easy way out... [It] is the ideology of banality... It is a totalitarian 
COX

ideology... Nationalism is also kitsch... But above all, nationalism is a negation, a negative category of the spirit...Nationalism thrives on relativism: it has no universal values, esthetic or ethical. (Kiš 1995: 15-18)

The second quote drives home a specific related point - about identity in general - even more forcefully:

I refuse to be categorized as a Jewish writer. I am opposed to every variety of minority literature: feminist, homosexual, Jewish, black. I am equally opposed to any tightly defined concept of national literature. I think of literature as my culture of origin. (Kiš 1995: 216)

We will now proceed to locate Kiš in the Baltics, that is, to find some common ground between Baltic and Balkan literatures. Then in the main part of the paper I will examine three points of intersection between Kišs intellectual and artistic concerns and salient areas of discussion among Baltic specialists. In conclusion, I will offer a few free-floating observations on recent Baltic literature in translation, informed both by the issues foregrounded at this conference and by my readings in the culture of the region as an East European historian.

\section{Locating Kiš in the Baltics}

There are precious few references to Latvia, Lithuania, or Estonia in the fiction and the voluminous essays and interviews of Kiš. As a matter of fact, Kiš wrote quite little about any other East European events of his day; he refers, concretely but infrequently, only to Hungary, Poland, and the USSR, and then for the most part only in connection to artistic trends or censorship. But in 1982 Kiš did write a short story set in Latvia and featuring a protagonist named "Valdemar D". The story, called "The Marathon Runner and the Race Official” (Kiš 2012: 98-105) was something Kiš had heard from a friend, the avant-garde painter Leonid Šejka, who in turn had neard it from Abram Tertz. The story concerns a political prisoner in the Gulag who is serving a fifty-year sentence; he is running, at the start very successfully, in a marathon, wearing a big number twenty-five. Various people, including his beloved Maria, persuade him to stop running at the half-way point, and he dies. This story was intended for inclusion in Kiš's short-story cycle The Encyclopedia of the Dead, but it remained uncollected and unpublished until after his death. 
The Lithuanian poet and scholar Tomas Venclova wrote a brief but very perceptive essay, called "Balkans and Baltics, Exploring the Common Ground Between These Two Regions". Kiš is not mentioned by name in this essay, given as a speech at a writers' congress in Zagreb in 1995, but one can easily imagine the Serbian-Hungarian-Jewish Yugoslav highlighting the same historical and cultural factors as the visiting Lithuanian. Venclova mentions that "[f] or a nationalist, the group is always more important than the individual, even God", (Venclova 2002: 71) in a direct echo of Kišss first philippic quoted above. Venclova designates the role of the "mirror images" of Communism and Stalinism in Eastern Europe's fateful twentieth century: they were the "mad" forces that terrorized the region and shaped so much of its history. Third, Venclova mentions the ethnic and confessional blend that constitutes both Balkan and Baltic demography, and notes that the region's cities even look alike: "[a]1l of the space between the Baltic and the Adriatic is the space of Baroque architecture”. (Venclova 2002: 72) Lastly, Venclova closes his speech with a noteworthy assertion of artistic ethics (never honor murder or the lie; observe universal standards of justice, not relativistic or national ones; place art above politics) that puts one very much in the mind of the challenges and claims discussed by Kiš in his famous essay of 1984, "Advice to a Young Writer". (Kiš 1995: 121-127)

Finally, it would be an oversight if I did not mention a passage from the Polish Nobel laureate Czesław Miłosz's memoir, Native Realm, in which the great "Lithuanian" echoes Kišs sentiments about two very important artistic processes: the necessity of rendering history specific so as to fathom its emotional and moral content, and the power proceeding from recognition that one's family and home region are both boundaries and the anchor of stability to the creative process. To wit:

$[\mathrm{M}] \mathrm{uch}$ is said these days about history. But unless we can relate it to ourselves personally, history will always be more or less of an abstraction... Doubtless every family archive that perishes, every account book that is burned, every effacement of the past reinforces classifications and ideas at the expense of reality. Afterward, all that remains of entire centuries is a kind of popular digest... If I mention my ancestors, if its because they are a source of strength for me. Thanks to them, the clothing and furniture of past epochs, the handwriting on yellowed documents, are not completely dead objects. The awareness of one's origins is like an anchor line plunged into the deep, keeping one within a certain range. (Miłosz 1968: 20) 
COX

\section{Intersections}

The following comments are not meant to discredit the Baltic discourse, or condemn cherished concepts as shibboleths. Rather they are offered as interactions or queries. Kiš himself had only limited time and energy to spend on issues such as these three that might have qualified him as a true public intellectual. Indeed, he did write many essays, but the theoretical ones among them were mostly concerned with delineating the importance of the Symbolists or articulating a Borgesian, nearly post-modernist approach to facticity in fiction.

Let us turn first to the issue of national identity, so popular in the late communist and transition periods in Eastern Europe. Kiš seldom used the word "identity", preferring simply the word "nationalism". Kiš was, at most, occasionally patriotic about, or simply of, the cultural achievements of South Slavic writers and the city of Belgrade, as well as the beauties of the SerboCroatian language (and, somewhat mysteriously, of a Serbian Orthodox burial, which did ensue after he died of lung cancer in Paris). But he saw nationalism's, or national identity's, direct impact on culture as divisive and limiting. For him identity arguably boiled down to this question: "What does it mean to your art to write as a (fill in the blank)?" In overarching terms the only answer to this question is to consider someone's mother tongue (Kiš was fond of saying that language was a writer's fate) and to account for the role of history in one's life and work - and that is history defined as "exposure" to politics. In terms of his own life, Kiš would always discuss not identity but his (revolutionary) literary models, the rigors of the authentic artistic life, and specific family predecessors with whom he identified. Even though Kišs father was Jewish and, especially at the beginning and end of his life, engaged with Jewish intellectuals and publications, he portrayed the significant number of Jewish protagonists in his works not as evidence that he was a Jewish writer but as a method of establishing a metaphor accessible to all as the marginalized, the victim - in short, the Other. Above all, Kiš found people's identification with collectives to be a "copout", an unproductive crutch, or, at worst, acquiescence in evil. He stressed contingent individualism, not identity, however cherished its properties might be.

Another important focus in cultural studies of post-communist states is post-colonialism. This theoretical concern seems to be growing in importance, especially in successor states to large, now-defunct multi-national states or empires, such as Latvia and Kišss Serbia (or even his father's post-Habsburg Hungary). Again, at the risk of sounding like a killjoy or throwing a wet blanket over the proceedings, it should be noted that Kiš never discussed issues related 
to post-colonialism, or at least to my understanding of it. Violeta Kelertas and others in the volume Baltic Postcolonialism (Kelertas 2006) associate the term with a restoration of subjectivity (or agency) and return to original language on the part of former colonial subjects, as well as with resexualization and retraditionalization of cultural modes. These are powerful theoretical tools, but few analysts have applied them (yet) to the former Yugoslavia, at least to areas outside Kosovo. Perhaps this is because traditional languages and mores were not threatened enough by either Yugoslav integralists, Soviet or homegrown Bolsheviks, or even the Ottoman sultans and grand vezirs. Kiš himself did not address issues such as these in the fictional or essay form, despite the fact that his father was murdered by the Nazis at Auschwitz (after having been hounded and harassed half to death by the Hungarian Arrow Cross) and his mother's family in Montenegro contained a number of heroes and heroines who were famous, well-nigh legendary, for resisting Turkish rule with both sword and pen. One is tempted to argue that Kiš tended to individualize, to disaggregate, if you will, hegemony into singular cases of suffering. Perhaps he did this even in his own case when Serbian nationalist critics began attacking his work in the 1970s. Kiš was not blind to the homogenizing and mobilizing power of ideology, and it is true that the perpetrators in his works are often unnamed or are depicted as masses or structural elements. But Kišs mistrust of "the system" does not seem tied to colonialism or imperialism but to the nature of society and group psychology in the first place.

A third intersection between Kiš's Balkan perspectives and topics prominent in Baltic culture and historiography is the idea of regions. Kiš wrote a fair amount about regions (as we all do, it would seem, from the first sentence of this paragraph, for instance). He saw regions as valid, historically attested affiliations; they could stand in for nations or subcultural identities. As a preliminary question we might ask: why is it necessary for anything to stand in for those collectivities if Kiš is such an emotional and intellectual Einzelgänger? I will offer five tentative responses to that question. First, Kiš was active at a time when regional concepts were very much in vogue among intellectuals in communist Europe; indeed his essays contributed some major innovations to the idea of "Central Europe" in a multi-decade discussion that was fueled by many literary figures he admired (see below). Second, his understanding of the family world and indeed the mental and material world destroyed by fascism was based on transnational similarities engendered by the Habsburg Empire. Third, Yugoslavia - a political innovation in which he believed - was also developing, or at least counting on, such social and cultural similarities. Fourth, Kiš might have reckoned that joining Europe, and expanding the notion of the canon to include "minor literatures" and ultimately, but necessarily, world 
COX

literature, would be easier for a raft of cultures than individual ones, despite the number of pilgrimages their young poets might make to Paris... And finally, since the history of the twentieth century was in Kišs view dominated by the savage expansion of two totalitarian states, and Eastern Europe was in the sights of both the Nazi and the Bolshevik camps, then it made geo-strategic sense to refer to groupings of Central European, Balkan and Baltic cultures or societies.

In his nonfiction writings, Kiš introduces unique regional designations for Europe: he refers to the Mediterranean, Russian, and Pannonian areas. But he spends more energy on the vaunted concept of Central Europe than anything else. Kiš effectively joined in the far-ranging multilateral conversation between writers and scholars as varied as Sándor Benamy, Joseph Brodsky, Daniel Chirot, Edvard Kocbek, Gyorgy Konrád, Milan Kundera, Claudio Magris, Miklós Mészöly, Czesław Miłosz, István Örkény, George Schöpflin, and William T. Vollmann. In the English-speaking world, one of the main outlets in which this revitalization or reassertion of a Central European regional identity took place was the highly regarded annual Cross Currents, published from 1982 to 1993, inclusive at the University of Michigan and then at Yale. The contributors to this discussion or debate all posited the existence, political or historical or cultural, of a "Central Europe". but they each emphasized different attributes of the grouping. All agreed that Central Europe was not the same thing as the German notion of Mitteleuropa, which implied German domination, and that Germany was not to be included. Otherwise, they found the region's uniqueness in some combination of the following properties: the prevalence of stable and sometimes tolerant multi-ethnic and multi-confessional societies over centuries of common life; a tendency towards a Habsburg or Danubian emphasis but with the certain inclusion of Poland; common musical and ethnomusical heritage and oral and poetic traditions; the pronounced interplay, inter alia, of Catholic and Jewish cultures; a modern predilection for irony, ambivalence, and formal experimentation in literary works; resistance to homogenization from outside forces, in particular Bolshevization; and nostalgia for "Europe," to which the member cultures once clearly belonged.

In his own work, Kiš shared many of these views. But he also made significant innovations to the idea of Central Europe. He expanded its definition, for instance, to northern Italy, the Baltic States, and, guardedly, the city of Vienna (though not all of Austria). In fact, Kiš's view of this region tends to focus more on cities than countryside or hinterland, so that, for instance, Bucharest and Belgrade pass muster. Quietly Kiš adds a simple statement that is actually worthy of headlines in the context of this debate: the Europe to which Central Europe compares itself includes not just Judeo-Christian traditions, but also 
the Byzantine and the Ottoman ones. Finally, Kiš asserts that the factors that link the peoples of this region might be different in different historical periods; reading between the lines, one could even be forgiven for coming away with the impression that Kiš believes Central Europeanness might be an individual affiliation, not a societal one. What if we carry regionalism within us, as constituent parts of other groupings, the way regions of a country can belong to a bigger region (the Austrian crown lands to the Germanic world, while much of the Habsburg Empire was outside of the Holy Roman Empire, for instance) that does not include that entire country. In sum Kiš’s Central Europe is bigger than that of most other intellectuals, and the membership criteria, so to speak, are more flexible while also in some ways more precisely stipulated.

\section{Conclusions}

When writing this article, I read a number of Latvian, Lithuanian, and Estonian works of fiction in English translation, especially the recent ones, ${ }^{1}$ as well as several historical surveys. Adding to this modest fact base the impressions I have gathered walking around and visiting historic sites in this gorgeous city of Riga, I can well understand the demographic and foreign policy challenges facing this part of the Baltics. And, yes, one of the authors I have been reading is Jaan Kross...

If I were to list the themes that jumped out at me (as a historian and a Balkanist) most, I would say the following things. Probably few of them will be new to this audience, but perhaps their inflection through a southeast European lens will be interesting at least. Baltic literature evinces, somewhat in chronological order from older works to contemporary ones:

- the burden of recurrent feudalism and internal colonization;

- wide-ranging explorations of the necessity and properties of resistance;

- a familiar (to me) valorization of "village prose";

1 These works include: Inga Abele, High Tide (2013); Eugenijus Ališanka, City of Ash (2000); Kazys Boruta, Whitehorn's Windmill; Jānis Ezeriņš, The Tower and Other Stories (2012); Ričardas Gavelis, Vilnius Poker (2009); Violeta Kelertas, ed., "Come into My Time": Lithuania in Prose Fiction, 1970-90 (1992); Jaan Kross, The Czar's Madman (1999) and Sailing Against the Wind (2012); Viivi Luik, The Beauty of History (2008); Tõnu Õnnepalu, Border State (2000) and Radio (2014); Kajar Pruul, ed., Estonian Short Stories (1996); Alfreds Straumanis, ed., Confrontations with Tyranny: Six Baltic Plays with Introductions (1977), along with three other similar anthologies that appeared later; and Friedebert Tuglas, The Poet and the Idiot (2007) and Riders in the Sky: A Selection of Short Stories (1982). 
COX

- ambiguity vis-a-vis "Europe" or the European Union;

- a remarkable sense of the common fate shared with other former communist states of "Eastern Europe" - and one that arguably outweighs the regional designation of "Baltic";

- the danger, even now, of a "stolen past," including one that is interpreted out of existence for political reasons;

- diversity couched in terms of shifting borders and overlapping maps;

- a need to categorize that is tempered by intellectual agility or emotional flexibility and is expressed as gamesmanship, play, or simply chance in other words, an almost post-modern approach to cultural or emotional constants.

When acknowledging the uniqueness of Latvian and other Baltic cultures, including those of other language groups who lived or live here, and while explaining the zealous and nearly ubiquitous preoccupation with national cultures here, I find it useful to recall both the Baltic States' colonial past and precarious international position. Concerning the colonial injustice experienced with regard to "personal options", early Baltic nationalists naturally wanted a system in which

occupational choice did not require the abandonment of identity as Estonians or Latvians, and ... the culture in which they were raised was respectable and portable as they moved up in the socio-economic hierarchy. (Plakans 2011: 224)

At the same time it strikes me that the study of culture in the Baltic States manifests that contingency and need for contextualized understanding that are the primary implements in the historian's toolbox. In Balkan history, for instance, we find ourselves reminding nationalist politicians and uninitiated journalists that Tsar Dušan's "Serbian Empire" of the $14^{\text {th }}$ century was a dynastic and military accretion, and a multi-national one at that; Dušan considered himself lord of the Serbs, Albanians, and Greeks, and anyway his goal was to take Byzantium - for the sake of ruling Byzantium, not making it Serbian. No one underscores this erudite indeterminacy better than the "Lithuanian" Miłosz himself, who writes over and over that historical polities in the Baltic region were not nation states but rather multi-ethnic and multiconfessional feudal formations. And he notes further, as I read him, that an exposed location on the "marchlands" of the West is not the same thing as fatalistic subjugation to the determining power of a "fracture zone" of the 
supposed fault line between clashing civilizations, or of the proud verdict of the antemurale christianitatis; most important are the condition of plurality and the legacy of colonization itself.

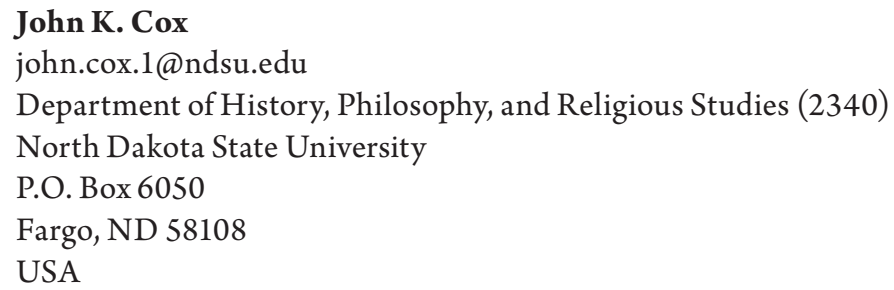

\section{Bibliography}

Kasekamp, A. 2010. A History of the Baltic States. New York: Palgrave Macmillan.

Kelertas, V., ed. 2006. Baltic Postcolonialism. Amsterdam: Rodopi.

Kiš, D. 1995. Homo Poeticus: Essays and Interviews, edited by Susan Sontag. New York: Farrar, Straus, Giroux.

Kiš, D. 2012. The Lute and the Scars: Stories. Translated by John K. Cox. Champaign, IL: Dalkey Archive Press.

Milosz, C.1968. Native Realm: A Search for Self-Definition. Translated by Catherine S. Leach. Garden City. New York: Doubleday.

Milosz, C. 1981. The Issa Valley. New York: Farrar, Straus, Giroux.

Plakans, A. 2011. A Concise History of the Baltic States. New York: Cambridge University Press.

Purs, A. 2012. Baltic Facades: Estonia, Latvia and Lithuania since 1945. London: Reaktion.

Venclova, T. 2002. Forms of Hope: Essays. Riverdale-on-Hudson, NY: Sheep Meadow Press.

Venclova, T. 2006. Vilnius: EineStadt in Europa. Translated by Claudia Sinnig. Frankfurt: Suhrkamp. 